University of Nebraska - Lincoln

DigitalCommons@University of Nebraska - Lincoln

1996

\title{
Microbial Reduction of Crystalline Iron(III) Oxides: Influence of Oxide Surface Area and Potential for Cell Growth
}

\author{
Eric E. Roden \\ The University of Alabama, ERODEN@BIOLOGY.AS.UA.EDU \\ John M. Zachara \\ Pacific Northwest National Laboratory, john.zachara@pnl.gov
}

Follow this and additional works at: https://digitalcommons.unl.edu/usdoepub

Part of the Bioresource and Agricultural Engineering Commons

Roden, Eric E. and Zachara, John M., "Microbial Reduction of Crystalline Iron(III) Oxides: Influence of Oxide Surface Area and Potential for Cell Growth" (1996). US Department of Energy Publications. 214. https://digitalcommons.unl.edu/usdoepub/214

This Article is brought to you for free and open access by the U.S. Department of Energy at DigitalCommons@University of Nebraska - Lincoln. It has been accepted for inclusion in US Department of Energy Publications by an authorized administrator of DigitalCommons@University of Nebraska - Lincoln. 


\section{Microbial Reduction of Crystalline Iron(III) Oxides: Influence of Oxide Surface Area and Potential for Cell Growth}

\author{
ERICE. RODEN*,† AND \\ J OHN M. ZACHARA
}

Department of Biological Sciences, The University of Alabama, Box 870344, Tuscaloosa, Alabama 35487-0344, and Earth and Environmental Sciences Center, Battelle Pacific National Laboratory, MS K3-61, Richland, Washington 99352

Quantitative aspects of microbial crystalline iron(III) oxide reduction were examined using a dissimilatory iron(III) oxide-reducing bacterium (Shewanella alga strain $\mathrm{BrY}$ ). The initial rate and long-term extent of reduction of a range of synthetic iron(III) oxides were linearly correlated with oxide surface area. Oxide reduction rates reached an asymptote at cell concentrations in excess of $\approx 1 \times 10^{9} / \mathrm{m}^{2}$ of oxide surface. Experiments with microbially reduced goethite that had been washed with $\mathrm{pH} 5$ sodium acetate to remove adsorbed $\mathrm{Fe}(\mathrm{II})$ suggested that formation of a Fe(II) surface phase (adsorbed or precipitated) limited the extent of iron(III) oxide reduction. These results demonstrated explicitly that the rate and extent of microbial iron(III) oxide reduction is controlled by the surface area and site concentration of the solid phase. Strain BrY grew in media with synthetic goethite as the sole electron acceptor. The quantity of cells produced per micromole of goethite reduced $\left(2.5 \times 10^{6}\right)$ was comparable to that determined previously for growth of BrY and other dissimilatory Fe(III)reducing bacteria coupled to amorphous iron(III) oxide reduction. BrY reduced a substantial fraction $(8-18 \%)$ of the crystalline iron(III) oxide content of a variety of soil and subsurface materials, and several cultures containing these materials were transferred repeatedly with continued active $\mathrm{Fe}(\mathrm{III})$ reduction. These findings indicate that $\mathrm{Fe}(\mathrm{III})$ reducing bacteria may be able to survive and produce significant quantities of $\mathrm{Fe}(\mathrm{II})$ in anaerobic soil and subsurface environments where crystalline iron(III) oxides (e.g., goethite) are the dominant forms of Fe(III) available for microbial reduction. Results suggest that the potential for cell grow th and Fe(II) generation will be determined by the iron(III) oxide surface site concentration in the soil or sediment matrix.

\section{Introduction}

Reduction of iron(III) oxides has an important influence on the geochemistry of anaerobic soils and sediments (13), and recent studies have demonstrated that direct microbial (i.e., enzymatic) catalysis is responsible for most of the Fe(III) reduction occurring under non-sulfidogenic anaerobic conditions $(3,4)$. Amorphous iron(III) oxide is considered to be the predominant form of $\mathrm{Fe}(\mathrm{III})$ reduced in these environments (3), because very little of the iron in crystalline iron(III) oxides (e.g., goethite, hematite) has appeared available for reduction by $\mathrm{Fe}$ (III)-reducing bacteria (5-7). However, in many soils, sediments, and subsurface materials crystalline iron(III) oxides are more abundant than amorphous iron(III) oxide (8). Reduction of even a minor amount of these compounds could significantly influence the inorganic geochemistry of such environments by causing the release of soluble $\mathrm{Fe}^{2+}$ and other adsorbed species (e.g., phosphate, trace metals) or byprovidinga reactiveFe(II) surface capableof participating in secondary redox or mineral-forming reactions.

Although particle size and surface area have been implicated as major factors controlling the susceptibility of various iron(III) oxides to microbial reduction $(3,9)$, explicit experimental evidence for this assertion is not yet available. Increased understanding of how these and other factors may control the rate and extent of microbial reduction of different iron(III) oxide phases is important given the influence this process has on the geochemistry of anaerobic environmentsand particularlyin light of recent reports which suggest that microbial iron(III) oxide reduction may play an important rolein the degradation of various kinds of organic contaminants (10-16). In this study, we examined the microbial reduction of several different iron(III) oxides using the dissimilatory Fe(III)-reducing bacterium Shewanella alga strain BrY (17) (hereafter referred to as strain BrY) as a test organism. We sought to quantitatively assess theinfluence of iron(III) oxide surfacerelated factors on the initial rate and long-term extent of microbial iron(III) oxide reduction. In addition, we evaluated the potential for bacterial growth with synthetic and soil-born crystalline iron(III) oxides as electron acceptors.

\section{Materials and Methods}

Growth Mediaand Cultivation. Strain BrY was maintained on tryptic soy agar slants ( $30 \mathrm{~g} \mathrm{~L}^{-1}$ tryptic soy broth (TSB), $15 \mathrm{~g} \mathrm{~L}^{-1}$ agar; Difco Laboratories, Detroit, MI) incubated aerobically at $30^{\circ} \mathrm{C}$ and routinely cultured in liquid TSB medium on a rotary shaker (150 rpm) at $37^{\circ} \mathrm{C}$.

Thecomposition of basal medium used for iron(III) oxide reduction experiments was $(\mathrm{mM}): \mathrm{NH}_{4} \mathrm{Cl}$ (28.0), $\mathrm{KH}_{2} \mathrm{PO}_{4}$ (4.4), $\mathrm{CaCl}_{2} \cdot 2 \mathrm{H}_{2} \mathrm{O}$ (1.0), and 1,4-piperazinediethanesulfonic acid (PIPES) (10.0). The medium was supplemented with $10 \mathrm{~mL}$ each of vitamin and tracemineral solutions described previously (7). Unless specified otherwise, sodium lactate (5 or $30 \mathrm{mM}$ ) served as the electron donor for Fe(III)

* Correspondingauthor telephone: (205) 348-0556; fax: (205) 3481786; e-mail address: ERODEN@BIOLOGY.AS.UA.EDU

† The University of Alabama.

‡ Battelle Pacific National Laboratory. 
reduction experiments. The $\mathrm{pH}$ of the basal medium (including lactate) was adjusted to 7.0 prior to dispensing it into anaerobic pressure tubes (Bellco Glass, Vineland, $\mathrm{NJ}$ ) or serum bottles containing the appropriate quantity of iron(III) oxide. The medium was bubbled for 5-10 min with $\mathrm{N}_{2}$ that had been passed through a column of hot reduced copper to remove traces of $\mathrm{O}_{2}$. The tubes or vials werecapped with thick butyl rubber stoppers, crimp sealed, and autoclaved $\left(121^{\circ} \mathrm{C}, 20 \mathrm{~min}\right)$. Fe(III) reduction experiments were conducted at 30 or $35^{\circ} \mathrm{C}$ in the dark.

Preparation and Characterization of Iron(III) Oxides. Amorphous iron(III) oxide was prepared by neutralizing a $0.4 \mathrm{M}$ solution of $\mathrm{FeCl}_{3} \cdot 6 \mathrm{H}_{2} \mathrm{O}$ with $1 \mathrm{M} \mathrm{NaOH}$ and washing with distilled water (18). The amorphous Fe(III) gel was used wet, except for one experiment for which a portion of the gel was freeze-dried and passed through a $100 \mu \mathrm{m}$ sieve prior to addition to Fe(III)-reducing medium. This procedure led to the formation of 2-line ferrihydrite, as revealed by a high degree of particleaggregation and broad X-ray diffraction peaks at 2.5 and $1.4 \AA$, consistent with those described by Schwertmann and Cornell (19).

Three different goethites ( $\alpha-\mathrm{FeOOH})$ of varying surface area weresynthesized. Medium surface area (MSA) goethite was formed by adjusting the $\mathrm{pH}$ of $\mathrm{a} 0.4 \mathrm{M}$ solution of $\mathrm{FeCl}_{3}{ }^{\circ-}$ $6 \mathrm{H}_{2} \mathrm{O}$ to 13 with $4 \mathrm{~N} \mathrm{NaOH}$ and incubating the suspension at $70^{\circ} \mathrm{C}$ for $16 \mathrm{~h}$ (19). Low surface area (LSA) goethite was produced from a portion of the same suspension used to form MSA goethite, with the exception that the suspension was aged at $70^{\circ} \mathrm{C}$ for 3 days. Both LSA and MSA goethite were washed by centrifugation until the $\mathrm{Cl}^{-}$concentration was $<0.5 \mathrm{mM}$. The oxides were then freeze-dried and passed through a 100- $\mu \mathrm{m}$ sieve. High surface area (HSA) goethite was synthesized by slow (48 $\mathrm{h}$ ) air oxidation of $\mathrm{FeCl}_{2}(50 \mathrm{mM})$ in a circumneutral bicarbonate (5 mM)buffered solution (20). The resulting suspension was washed free of salt by dialysis, freeze-dried, and passed through a $100-\mu \mathrm{m}$ sieve. The different goethites were examined by X-ray diffraction (XRD) and showed no evidence of crystalline impurities. Broadening of XRD diffraction maxima was observed for the MSA and HSA goethite consistent with their particle size (21).

Hematite $\left(\mathrm{Fe}_{2} \mathrm{O}_{3}\right.$ powder) was purchased from Baker Chemical Co. The hematite was heated at $750{ }^{\circ} \mathrm{C}$ for $2 \mathrm{~h}$, allowed to cool, and passed through a $100-\mu \mathrm{m}$ sieve prior to addition to Fe(III)-reducing medium. X-ray diffraction analysis confirmed the identity and high degree of crystallinity of this material.

The amount of $\mathrm{Fe}(\mathrm{III})$ that could be extracted from the different iron(III) oxides with (i) $0.25 \mathrm{M}$ hydroxylamine hydrochloride in $0.25 \mathrm{M} \mathrm{HCl}$ and (ii) ammonium oxalate was determined as described below. The total Fe content ( $\mu$ mol goxide ${ }^{-1}$ ) of theoxides was determined by dissolving them in $12 \mathrm{~N} \mathrm{HCl}$ and analyzing the Fe content of diluted portions of the extract as described below.

The surface area of the different freeze-dried iron(III) oxides was determined by multipoint BET analysis with $\mathrm{N}_{2}$ as the adsorbate. It was not possible to determine the surface area of the amorphous Fe(III) gel by BET analysis. So that results obtained with this material could beincluded in quantitativeanalyses of the rate/ extent of microbial iron(III) oxide reduction as a function of oxide surface area, we adopted a value of $600 \mathrm{~m}^{2} \mathrm{~g}^{-1}$ based on extensivediscussions and recommendations given in refs 22 and 23 . This value is similar to that of $500 \mathrm{~m}^{2} \mathrm{~g}^{-1}$ determined by Zinder et al.
(24) for comparableamorphousiron(III) oxidepreparations by particle size measurements.

The different iron(III) oxides were examined by transmission electron microscopy (TEM) to determinethetypical size range of individual particles and to assess the degree of particleaggregation. Unstained whole mounts of oxides suspended in distilled water were prepared on formvar and carbon-coated 200-nm copper grids and examined with a Phillips 400-TEM working at $120 \mathrm{kV}$. To obtain a standard measure of particles size for oxides of different morphology, length-width measurements were inserted into thesimple formula (e.g., see ref 25):

$$
\text { average particle size }=(\text { length } \times \text { width })^{1 / 2}
$$

Soil and SubsurfaceMaterials. Previously characterized (26-28) soil and subsurface materials containing iron(III) oxides were also used in Fe(III) reduction experiments. The natural materials fell into two categories on the basis of their mineralogy and the nature of the particle association of the iron(III) oxide fraction: (i) iron(III) oxide-coated quartzitic sands and (ii) iron(III) oxide/layer silicate mixtures. The iron(III) oxide-coated sands (Dover, Milford, and Oyster) were Pliocene and Pleistocene Age Atlantic coastal plain sediments collected from gravel pits in Virginia and Delaware. Theiron(III) oxide/layered silicatemixtures were obtained from ultisols in Tennessee (Holston/Cloudland, Typic Fragiudult; designated $\mathrm{HC}$ ) and North Carolina (Cecil/Pacolet, Typic Hapludult; designated CP). Thesoils differ in their clay mineralogy with the $\mathrm{HC}$ being dominated by 2:1 layer silicates and the CP being dominated by kaolinite; the HC consequently exhibited a much higher cation exchange capacity than the CP. Samples from different horizons of the soils were used: $\mathrm{HC}-90\left(\mathrm{BT}_{\mathrm{x}}, 80-\right.$ $12 \mathrm{~cm}), \mathrm{HC}-92(\mathrm{E}, 15-30 \mathrm{~cm}), \mathrm{HC}-93\left(\mathrm{~B}_{\mathrm{t}}, 40-80 \mathrm{~cm}\right), \mathrm{HC}-$ 95 (C, 120-190 cm), CP-70 (BC, 40-90 cm), CP-71 (Ap, 0-15 $\mathrm{cm})$, and $\mathrm{CP}-72\left(\mathrm{~B}_{\mathrm{t}}, 15-40 \mathrm{~cm}\right)$. The amount of Fe(III) extractable by hydroxylamine hydrochloride, ammonium oxalate, and dithionite-citratewas determined as described below. Additional properties of thesematerialsare reported elsewhere (26-28).

Fe(III) Reduction Experiments with TSB Grown Cells. Previous studies (29) have shown that strain BrY produces large quantities of iron(III) reductase during late exponential/early stationary growth phase in aerobic TSB medium. A series of Fe(III) reduction experiments was therefore conducted using late exponential phase (16 h) TSB-grown strain BrY cells. In most cases, unwashed, undiluted $\mathrm{N}_{2}$-sparged cell suspensions were prepared directly from theTSB cultures under sterileconditions. This approach allowed sterile acquisition of a large number of cells that were free of the chelator citrate typically present in liquid Fe(III)-reducer culture media. For some experiments, TSB-grown cells were collected by centrifugation (7500g, $10 \mathrm{~min}, 4^{\circ} \mathrm{C}$ ), resuspended in anaerobic PIPES buffer (10 mM, pH 7), centrifuged again, and resuspended in anaerobic buffer prior to use as inoculum. Aliquots $(0.1-2$ $\mathrm{mL}$ ) of washed and unwashed cell suspensions wereadded to pressure tubes containing sufficient Fe(III)-reducing medium to yield a total culture volume of $10 \mathrm{~mL}$. Unless specified otherwise, the initial cell density in these cultures was $\approx 2 \times 10^{8} \mathrm{~mL}^{-1}$, asestimated by therelationship between the $A_{600}$ of TSB cultures and direct cell counts (see below) of washed and unwashed cell suspensions prepared from the cultures. All cell additions, transfers, and culture 
samplings were performed with sterilesyringes and needles that had been flushed with sterile, $\mathrm{O}_{2}$-free $\mathrm{N}_{2}$.

Growth with GoethiteReduction. Growth experiments with MSA goethite $\left(500 \mathrm{mmol} \mathrm{L}^{-1}\right)$ as the sole electron acceptor and lactate $(5 \mathrm{mM})$ or $\mathrm{H}_{2}(30 \mathrm{~mL})$ as the sole electron donor were conducted in 100-mL culture bottles. Starting with an inoculum of TSB-grown cells, strain BrY wastransferred fivetimes in lactate-MSA goethitemedium prior to conducting thegrowth experiments. Transferswere achieved by adding a 1-mL inoculum from an existing culture to $10 \mathrm{~mL}$ of fresh medium. The inoculum used for the final growth experiments was a culture containing an initial lactateconcentration of only $3 \mathrm{mM}$, so that an electron donor-free control culture could be obtained. The $\mathrm{H}_{2}-$ MSA goethitemedium contained $10 \mathrm{mM}$ malateas a carbon (but not electron donor) source (30). The cultures were sampled for Fe(II), lactate, and cell numbers at 2-4-day intervals over an 18-day static incubation at $35^{\circ} \mathrm{C}$.

Analytical Techniques. Total Fe(II) in the cultures was determined by extraction (1-2 h) with $0.5 \mathrm{M} \mathrm{HCl}$ and measurement of $\mathrm{Fe}(\mathrm{II})$ in a $0.2-\mu \mathrm{m}$ membrane-filtered portion of the extract with $5-10 \mathrm{~mL}$ of FerroZine $\left(1 \mathrm{~g} \mathrm{~L}^{-1}\right)$ in $50 \mathrm{mM}$ HEPES buffer (pH 7) (5). Dissolved Fe(II) was determined by passing a portion of culture through a $0.2-$ $\mu \mathrm{m}$ membrane filter directly into $5-10 \mathrm{~mL}$ of FerroZine. Total dissolved Fe was determined by adding a portion of filtered culture to 5-10 mL of FerroZine followed by the addition of $0.25 \mathrm{~mL}$ of $10 \%$ hydroxylamine hydrochloride to reduce all Fe to Fe(II). The amount of Fe(II) adsorbed to iron(III) oxide surfaces after incubation with BrY was estimated by addinga sample $(0.5 \mathrm{~mL})$ of culture (containing ferrihydrite or goethite) to $2 \mathrm{~mL}$ of $\mathrm{N}_{2}$-bubbled $1 \mathrm{M}$ sodium acetate ( $\mathrm{pH}$ 5) contained in a sealed, $\mathrm{N}_{2}$-flushed serum vial. After a 24-h extraction in the dark at $28^{\circ} \mathrm{C}$ on a $100 \mathrm{rpm}$ rotary shaker, a $0.2-\mu \mathrm{m}$ filtered portion of the extract was assayed for $\mathrm{Fe}(\mathrm{II})$ with FerroZine. Adsorbed Fe(II) was calculated as the difference between acetate-extractable and dissolved $\mathrm{Fe}(\mathrm{II})$.

Oxalate ( $10 \mathrm{~mL}$ of $28 \mathrm{~g} \mathrm{~L}^{-1}$ ammonium oxalate/ $15 \mathrm{~g} \mathrm{~L}^{-1}$ oxalic acid, pH 3.0; 5) extractions of 20-50-mg portions of the synthetic iron(III) oxides or iron(III) oxide-containing soil materials were conducted in dark vials for $4 \mathrm{~h}$ at room temperature; the contents of the vials were mixed with a magnetic stir bar during extraction. Hydroxylamine hydrochloride $\left(10 \mathrm{~mL}\right.$ of $0.25 \mathrm{M} \mathrm{NH}_{2} \mathrm{OHHCl}$ in $0.25 \mathrm{M} \mathrm{HCl}$; 6) and citrate-dithionite ( $10 \mathrm{~mL}$ of $0.2 \mathrm{M}$ sodium citrate/ $0.35 \mathrm{M}$ acetic acid, $\mathrm{pH} 4.8$ plus $0.5 \mathrm{~g}$ of sodium dithionite; 31) extractions of $20-50-\mathrm{mg}$ portions of synthetic or soil iron(III) oxides were conducted at room temperature for $1 \mathrm{~h}$ with magnetic stirring. The Fe(III) concentration in these extracts and diluted portions of $12 \mathrm{~N} \mathrm{HCl}$ digests was determined by reducing Fe(III) with hydroxylamine (overnight incubation at room temperature) and measuring Fe(II) with FerroZine.

Lactate concentrations were determined by HPLC (32). Cell numbers in the lactate-MSA goethite growth cultures were quantified by taking advantage of the fact that crystalline iron(III) oxides such as goethite are rapidly dissolved by oxalate in the presence of Fe(II) (33). Onemilliliter portions of the cultures were fixed with $0.1 \mathrm{~mL}$ of $25 \%$ glutaraldehyde (in a $20-\mathrm{mL}$ glass vial), and $9 \mathrm{~mL}$ of $0.2-\mu \mathrm{m}$ filtered oxalate (same composition as above) was added. Immediately after mixing, $1 \mathrm{~mL}$ of the suspension was transferred to $9 \mathrm{~mL}$ of filtered oxalate. One milliliter of a filtered, anaerobic solution of ferrous ethylenediam- monium sulfate ( $100 \mathrm{mM})$ was added, and the vials were swirled periodically for $10 \mathrm{~min}$ until all of the goethite particles had dissolved. Five milliliters of the resulting solution was transferred to a $25 \mathrm{~mm}$ diameter filter tower, $0.5 \mathrm{~mL}$ of filtered acridineorangesolution $(0.1 \%)$ was added, and the contents of the tower were mixed by swirling. After 3-4 min, the solution in the tower was filtered through a black 0.2- $\mu \mathrm{m}$ nucleopore filter, and the number of cells on the filter was determined by epiflourescence microscopy.

Cell numbers in suspensions of unwashed and washed TSB-grown BrY cells were determined by diluting the suspensions 100-fold and counting the number of cells in $50-\mu \mathrm{L}$ portions of the dilutions by acridine orange staining and epiflourescence microscopy as described above.

\section{Results}

Control Experiments. We checked for the presence of organic Fe chelators in the TSB growth medium used as inoculum for many of the experiments conducted in this study, as such compounds could potentially affect therate/ extent of microbial iron(III) oxide reduction. The addition of TSB $(0.15 \% \mathrm{wt} / \mathrm{vol}$, equal to the standard addition used in other experiments) to sterile medium containing either $20 \mathrm{mmol} \mathrm{\textrm {L } ^ { - 1 }}$ amorphous Fe(III) or $200 \mathrm{mmol} \mathrm{L}^{-1} \mathrm{MSA}$ goethite resulted in the solubilization of a minor amount of Fe $(3.2 \pm 2.3$ and $16.4 \pm 7.9 \mu \mathrm{M}$ for the two oxides, respectively; error represents range of duplicatetubes), 23 $29 \%$ of which was present as dissolved $\mathrm{Fe}^{2+}$. An equivalent amount of EDTA solubilized 30-90-fold more Fe (112 \pm 10.2 and $1517 \pm 180 \mu \mathrm{M}$ for amorphous Fe(III) and MSA goethite, respectively; $2-5 \%$ present as $\mathrm{Fe}^{2+}$ ).

Addition of TSB to medium inoculated with washed $\mathrm{BrY}$ cells increased the initial rate of amorphous $\mathrm{Fe}(\mathrm{III})$ and MSA goethite reduction by 27 and 41\%, respectively. By comparison, a 3-fold lower amount of EDTA (0.05\%) caused a substantially greater enhancement of therate of reduction of these two oxides (75\% and $139 \%$, respectively) (Roden and Zachara, unpublished data).

Previous studies of iron(III) oxide reduction by strain $\mathrm{BrY}$ (30) and other dissimilatory Fe(III)-reducing bacteria (e.g., refs 7 and 34) have been conducted in bicarbonatebuffered medium. To check whether or not the sulfonic acid groups of the PIPES buffer used in this study could promote iron(III) oxide reduction in a manner analogous to that of the carboxylic acid groups of metal chelators such as ethylenediaminetetraacetic acid (EDTA) or nitrilotriacetic acid (NTA), we compared Fe(III) reduction by TSBgrown BrY cells in PIPES- versus bicarbonate-buffered lactate-MSA goethitemedium. Initial rates of MSA goethite reduction in PIPES- and bicarbonate-buffered medium $\left(0.906 \pm 0.066\right.$ and $0.807 \pm 0.064 \mu \mathrm{mol}$ of $\mathrm{Fe} \mathrm{L}^{-1} \mathrm{~min}^{-1}$, respectively) were not significantly different from one another (t-test, $\mathrm{p}<0.05$ ). The amount of Fe(III) reduced after a 30-day incubation was also similar in the two types of buffer $\left(10.78 \pm 2.21\right.$ and $9.53 \pm 0.94 \mathrm{mmol}$ of $\mathrm{Fe} \mathrm{L}^{-1}$, respectively).

Effect of Iron(III) Oxide Concentration and Surface Area on Initial Rates of Fe(III) Reduction. A preliminary comparison of amorphous Fe(III), MSA goethite, and hematite reduction by TSB-grown BrY cells showed that $\approx 20$ times more amorphous Fe(III) than goethite and $\approx 50$ timesmoregoethitethan hematite was reduced over a 5-day incubation period (data not shown). This trend was qualitatively consistent with thetrend of decreasing particle size and increasing surface area of these oxides (Table 1). 


\section{Characteristics of Synthetic Iron(III) Oxides}

\section{oxide}

amorphous Fe(III) 2-line ferrihydrite HSA goethite MSA goethite LSA goethite hematite

morphology
isometric ${ }^{a}$
aggregated
lath
lath
lath
spheroid

\section{typical particle} size range $(\mathrm{nm})$ surface

area $\left(\mathrm{m}^{2} \mathbf{g}^{-1}\right)$
$\% \mathrm{Fe}(\mathrm{III})^{b}$ extracted by

\begin{tabular}{cc}
\hline $\mathrm{NH}_{2} \mathrm{OH}$ & oxalate \\
100 & 100 \\
11.5 & 2.0 \\
0.754 & 0.805 \\
0.075 & 0.118 \\
0.028 & 0.075 \\
0.077 & 0.052
\end{tabular}

initial Fe(III) reduction rate ${ }^{c}\left(\mathrm{nmol} \mathrm{m}^{-2} \mathrm{~min}^{-1}\right)$
$\% \mathrm{Fe}$ (III) reduced by $\mathrm{BrY}^{d}$

$$
\begin{gathered}
44.1 \pm 0.6 \\
19.8 \pm 1.0 \\
12.6 \pm 0.3 \\
2.7 \pm 0.1 \\
1.5 \pm 0.2 \\
0.64 \pm 0.03
\end{gathered}
$$

a From ref 19 consistent with observations made in this study, ${ }^{b}$ Relative to total Fe content determined by dissolution with $12 \mathrm{~N} H \mathrm{HCl} c{ }^{c}$ Derived from least-squares regression analysis of the linear portion $(n=3-6)$ of the initial Fe(III) reduction rate vs iron(III) oxide concentration plots shown in Figure 1. The 5-100 mmol L $\mathrm{m}^{-1}$ concentration range was used for all of the oxides except amorphous Fe(III) and hematite, for which concentration ranges of 1-10 and $10-50 \mathrm{mmol} \mathrm{L}^{-1}$, respectively, were used. Error terms refer to the standard error of the slope of the regression line. ${ }^{d}$ Slope of the linear least-squares regression lines shown in Figure 4. Error terms refer to the standard error of the slope of the regression line.
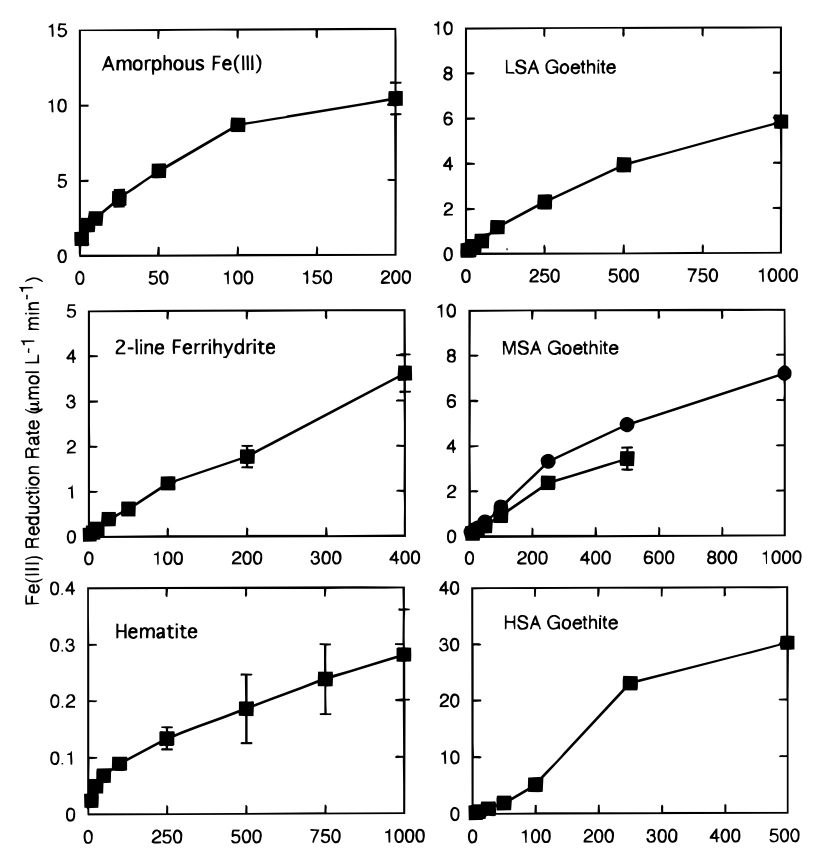

FIGURE 1. Initial rates of iron(III) oxide reduction by TSB-grown BrY cells at differentinitial Fe(III) concentrations. Error bars indic ate \pm the standard error of the slope of the linear least-squares regression of Fe(II) concentration versus time for each Fe(III) concentration; error bars not visible are smaller than the size of the symbol. The different symbols in the MSA goethite panel represent results of tw 0 separate experiments.

As an initial test of the influence of total oxide surface area on therate/ amount of Fe(II) production from an individual iron(III) oxide, we followed Fe(II) accumulation in media containing 500 versus $50 \mathrm{mmol}$ of MSA goethite $\mathrm{L}^{-1}$ (2450 $\mathrm{m}^{2} \mathrm{~L}^{-1}$ versus $245 \mathrm{~m}^{2} \mathrm{~L}^{-1}$ of MSA goethite). Approximately 10-fold more Fe(II) was produced in the former cultures over a 2-week period (data not shown).

Kinetic experiments employing a broad concentration range of different iron(III) oxides were conducted to examine the relationship between total oxide surface area and $\mathrm{Fe}(\mathrm{III})$ reduction rate. Initial rates of $\mathrm{Fe}(\mathrm{III})$ reduction were linear over a 24-h incubation period for all iron(III) oxides tested (data not shown). For each of the iron(III) oxides, the initial rate of reduction was proportional to the initial Fe(III) concentration (Figure 1). Complete saturation of Fe(III) reduction ratewith respect to $\mathrm{Fe}(\mathrm{III})$ concentration was not observed, although in most cases rates of Fe(III) reduction rates began to level off at the highest Fe(III) levels.

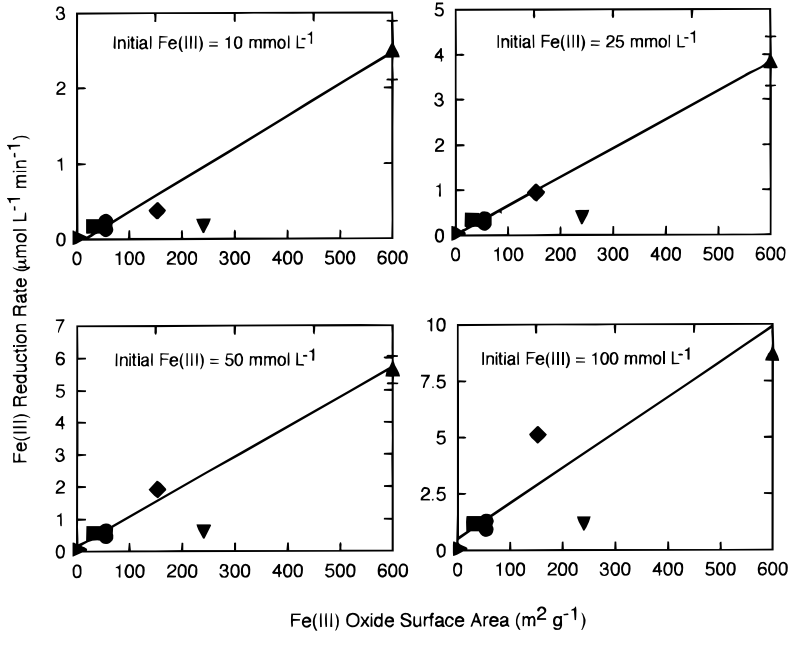

FIGURE 2. Initial rate of reduction of hematite (solid triangle pointing right), LSA goethite ( $\square)$, MSA goethite (๑), HSA goethite (४), 2-line ferrihydrite $(\boldsymbol{\nabla})$, and amorphous iron(III) oxide ( $\Delta$ ) in medium containing the same initial concentration of each iron(III) oxide plotted against oxide surface area. Error bars indic ate \pm the standard error of the slope of the linear least-squares regression of $\mathrm{Fe}$ (II) concentration versus time; error bars not visible are smaller than the size of the symbol. The solid lines are the result of linear regression analyses, excluding the results for 2-line ferrihydrite.

When normalized to iron(III) oxide surface area, initial rates of hematite; LSA, MSA, and HSA goethite; and amorphous $\mathrm{Fe}(\mathrm{III})$ reduction were similar, whereas the initial rate of the highly aggregated 2-line ferrihydrite was considerably lower (Table 1). These results are reflected in the linear correlation between initial Fe(III) reduction rate and iron(III) oxide surface area (excluding 2-line ferrihydrite) when all the oxides were present at thesamestarting concentration (10-100 $\mathrm{mmol}$ of Fe ${ }^{-1}$ ) (Figure 2). Because of the log-log relationship between average oxide particle size (defined as the mid-value of the typical particle size range listed in Table 1) and surface area (log surface area $=0.324-1.07 \times \log$ average particle size, $\left.r^{2}=0.85\right)$, a logarithmic relationship between initial Fe(III) reduction rate and average oxide particle size was evident (data not shown).

Effect of Cell Numbers on Fe(III) Reduction Rate. Medium containing $20 \mathrm{mmol} \mathrm{L}^{-1}$ amorphous Fe(III) gel or $200 \mathrm{mmol}^{-1} \mathrm{MSA}$ goethite was inoculated with washed cells to yield a range of cell densities of $2.7 \times 10^{7}-2.2 \times 10^{9}$ $\mathrm{mL}^{-1}$, and theinitial rate of $\mathrm{Fe}(\mathrm{III})$ reduction was determined over a 4-h incubation; the tubes were incubated on their sides on a $100 \mathrm{rpm}$ rotary shaker to facilitate interaction of 


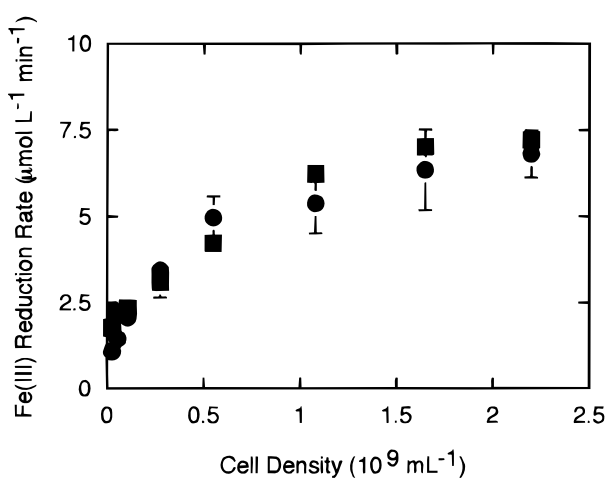

FIGURE 3. Initial rates of amorphous iron(III) oxide ( $\square$ ) and MSA goethite (O) reduction in cultures having a range of $w$ ashed, TSB grow $n$ B rY cell densities. Initial concentrations of amorphous Fe(III) and MSA goethite were 20 and $200 \mathrm{mmol} \mathrm{L}^{-1}$, respectively. Error bars show \pm the standard error of the slope of the linear leastsquares regression of $\mathrm{Fe}$ (II) concentration versus time for each cell density. Error bars not visible are smaller than the size of the symbol.

cells with oxide surfaces. The relationship between Fe(III) reduction rate and $\mathrm{BrY}$ cell density approximated a hyperbolic function (Figure 3), with the rate of Fe(III) reduction leveling off as cell density approached $10^{9} \mathrm{~mL}^{-1}$. Thiscell density corresponded to $\approx 1 \times 10^{9}$ cells $/ \mathrm{m}^{2}$ of iron(III) oxidesurface area for both amorphous Fe(III) and MSA goethite, which were added to the test medium to achieve approximately the same amount of oxide surface area per unit volume $\left(\approx 1 \mathrm{~m}^{2} \mathrm{~mL}^{-1}\right)$. Based on these results, for the range of $\mathrm{Fe}(\mathrm{III})$ concentrations included in the calculation of surfacearea-normalized Fe(III) reduction rates (see Table 1 ), the concentration of cells/ $\mathrm{m}^{2}$ oxidesurface ranged from 50 to $140 \%$ of the saturating concentration. This indicates that an excess of cells may not have been present at the highest oxide concentrations, a suggestion consistent with the fact that Fe(III) reduction rate:available oxide surface area ratios showed in some cases a modest (up to 50\%) decrease within the region of the plots chosen to calculate surface area-normalized Fe(III) reduction rates.

Effect of Oxide Surface Area on the Long-Term Extent of Fe(III) Reduction. Total Fe(II) concentrations were measured after 30 days of incubation to determinethelongterm extent (as a percentage of the initial Fe(III) concentration) of $\mathrm{Fe}(\mathrm{III})$ reduction in the various iron(III) oxide cultures. A 30-day period was chosen based on preliminary experiments with amorphous Fe(III) gel and MSA goethite, which indicated that Fe(III) reduction ceased after $\approx 3$ weeks of incubation. For a given oxide, a consistent fraction of the Fe(III) initially present in the cultures was reduced, as reflected by the linear correlation between total Fe(II) production and initial iron(III) oxideconcentration (Figure 4). An uncertainty in the hematite reduction results deserves mention in this regard. The long-term extent of hematite reduction in media having initial Fe(III) concentrations in excess of $250 \mathrm{mmol} \mathrm{L}^{-1}$ did not follow the linear relationship observed at lower concentrations. This deviation may have resulted from damage incurred to the cells during collision of the dense hematite particles (with bacteria attached to them) with the walls of the culture tubes during vigorous shaking prior to sample removal. Such cell damage was suggested by initial Fe(III) reduction ratestudiesin cultures with $>250 \mathrm{mmol} \mathrm{L}^{-1}$ hematite: initial rates of $\mathrm{Fe}(\mathrm{II})$ production in these cultures were linear for the first $10 \mathrm{~h}$ but declined considerably thereafter, in contrast to the other hematite concentrations in which Fe-
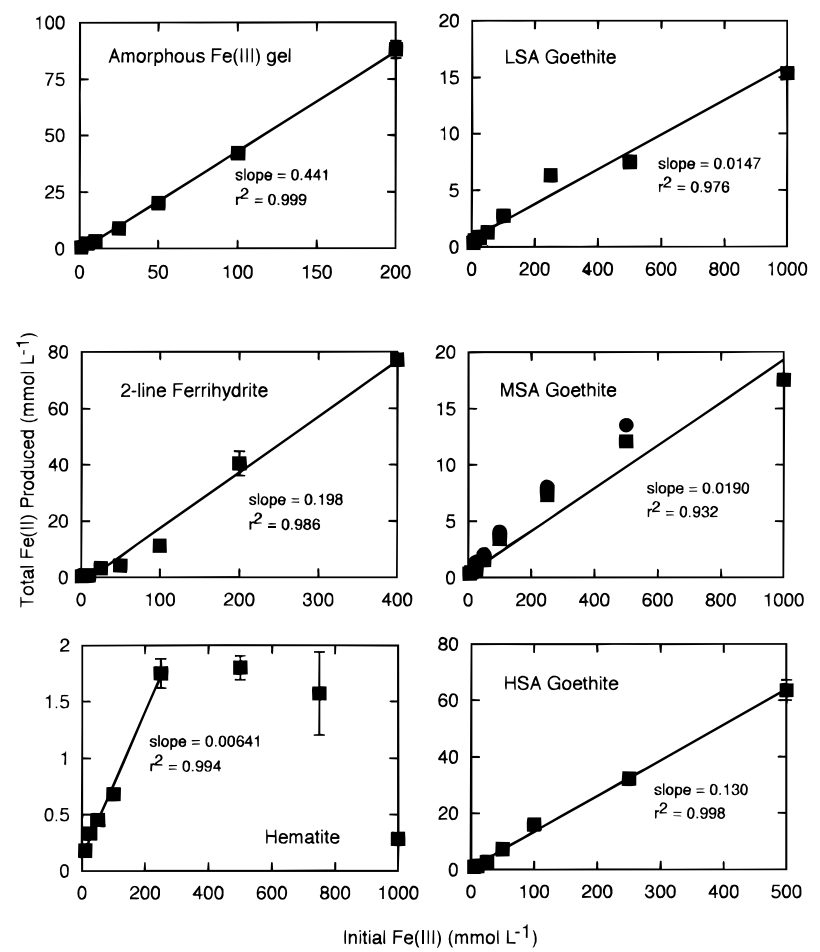

FIGURE 4. Total quantity of Fe(II) produced in cultures containing different initial iron(III) oxide concentrations after 30-day incubation. Results are the means of single determinations on duplicate cultures; error bars bracket the range of the duplicate samples; error bars not visible are smaller than the size of the symbol. The different symbols in the MSA goethite panel represent the results of two separate experiments.

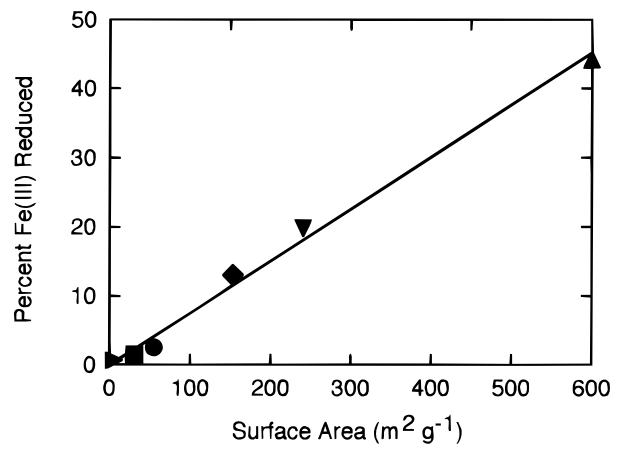

FIGURE 5. Percent of hematite (solid triangle pointing right), LSA goethite $(\square)$, MSA goethite $(\bullet)$, HSA goethite $(\diamond), 2$-line ferrihydrite $(\nabla)$, and amorphous iron(III) oxide ( $\mathbf{\Delta}$ ) reduced after 30 -day incubation plotted against oxide surface area. The values plotted are the slopes of the regression lines in Figure 4; error bars (standard error of these slopes) are smaller than the symbols. The solid line is the result of linear regression analysis.

(II) production was linear over a $24-\mathrm{h}$ period. Only the tubes having initial $\mathrm{Fe}(\mathrm{III})$ concentration of $\leq 250 \mathrm{mmol}$ $\mathrm{L}^{-1}$ were considered in thelinear regression shown in Figure 4.

The long-term extent of iron(III) oxide reduction was linearly related to the specific surface area of the different oxides (Figure 5). Analogous to the initial Fe(III) reduction rate data, a logarithmic relationship between extent of reduction and average particle size was evident (data not shown). The extent of amorphous Fe(III) gel reduction (44\%) was comparableto that observed previously for strain $\mathrm{BrY}(30)$ and other dissimilatory Fe(III) reducers and Fe(III)-reducing enrichment cultures $(5-7,34)$. The extent of MSA goethitereduction wasalso comparableto theextent 


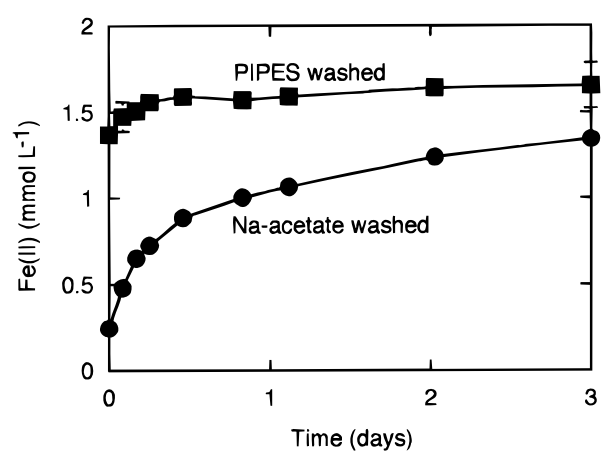

FIGURE 6. Reduction (by fresh TSB-grow $n$ BrY cells) of prereduced MSA goethite that had been w ashed with either $1 M$ sodium acetate (pH 5) or $10 \mathrm{mM}$ PIPES buffer (pH 7). The results are the means of single determinations of total (dissolved plus adsorbed) Fe(II) $(0.5$ $\mathrm{N} \mathrm{HCl}$ extraction) or duplicate cultures; error bars bracket the range of the duplicate samples.

of goethitereduction by other dissimilatory Fe(III)-reducing bacteria and Fe(III)-reducingenrichment cultures reported previously (5-7). Theextent of 2-lineferrihydritereduction was in agreement with what would be expected based on its surface area, indicating that its initial slow rate of reduction was not reflective of a long-term resistance to reduction.

Onlya small fraction ( $<10 \%$ ) of total $\mathrm{Fe}(\mathrm{II})$ wasaccounted for by dissolved $\mathrm{Fe}^{2+}$ in variousiron(III) oxide cultures after 30-day incubation. On a shorter time scale (24-h incubation), the ratio of dissolved:total Fe(II) declined from 10$25 \%$ in goethite and 2 -line ferrihydrite cultures with initial $\mathrm{Fe}(\mathrm{III})$ concentrations of $1-10 \mathrm{mmol}^{-1}$ to $<5 \%$ in cultures with $\geq 250 \mathrm{mmol}$ of $\mathrm{Fe}(\mathrm{III}) \mathrm{L}^{-1}$. In each instance, the major portion of the Fe(II) produced was either incorporated into an adsorption complexor a precipitateon theiron(III) oxide surface. Evidence for $\mathrm{Fe}^{2+}$ adsorption was obtained by extracting the oxides with $\mathrm{O}_{2}$-free $1 \mathrm{M}$ sodium acetate $(\mathrm{pH}$ 5) $(35,36)$, which liberated $64,58,71$, and $74 \%$ of the 0.5 $\mathrm{M} \mathrm{HCl}$-soluble $\mathrm{Fe}$ (II) present in the 2-line ferrihydrite, LSA goethite, MSA goethite, and HSA goethite cultures, respectively, after 24-h incubation.

Our observations of $\mathrm{Fe}^{2+}$ accumulation on iron(III) oxide surfaces suggested the possibility that saturation of surface hydroxyl groups with adsorbed Fe(II) or formation of a surface-coating phase could limit microbial Fe(III) reduction. This hypothesis was evaluated by washing previously reduced (by strain BrY) MSA goethite with $\mathrm{pH} 5$ sodium acetate to remove adsorbed $\mathrm{Fe}(\mathrm{II})$ and comparing the rate of reduction of this material by fresh TSB-grown cells to that of reduced goethite washed with pH 7 PIPES buffer. Washing with sodium acetate removed approximately $75 \%$ of the $0.5 \mathrm{M} \mathrm{HCl}$-extractable $\mathrm{Fe}(\mathrm{II})$ from the reduced goethite, whereas washing with PIPESbuffer removed $<10 \%$ of the $\mathrm{Fe}(\mathrm{II})$. The sodium acetate-extractable $\mathrm{Fe}(\mathrm{II})(\approx 1.4$ $\mathrm{mmol} \mathrm{L}^{-1}$ ) was close to thedivalent cation sorption capacity (1.2 $\mathrm{mmol} \mathrm{L}^{-1}$ ) for MSA goethite at this suspension concentration $\left(2.5 \times 10^{2} \mathrm{~m}^{2} \mathrm{~L}^{-1}\right)$ using the value measured for $\mathrm{Pb}^{2+}$ (37) by assuming a site density of 3 sites $\mathrm{nm}^{-2}$. A much larger amount of thesodium acetate-washed goethite was reduced $\left(\approx 1 \mathrm{mmol} \mathrm{L}^{-1}\right.$ ) over a 3-day period compared to the PIPES-washed material $\left(0.2 \mathrm{mmol}^{-1}\right)$ (Figure 6), indicating that the presence of adsorbed $\mathrm{Fe}(\mathrm{II})$ limited the extent of goethite reduction. The total quantity of $\mathrm{Fe}$ (II) formed in the sodium acetate- washed goethitecultures after 30-day incubation $\left(1.7 \mathrm{mmol} \mathrm{L}^{-1}\right)$ was comparable to that present in the PIPES-washed cultures $\left(1.9 \mathrm{mmol} \mathrm{L}^{-1}\right)$ and
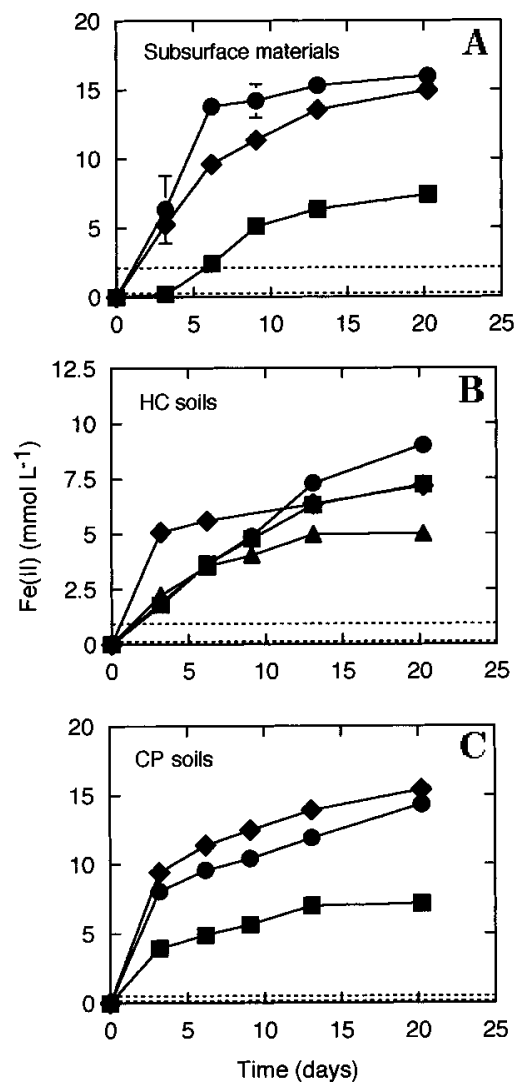

FIGURE 7. Reduction of Fe(III) in subsurface (Oyster, Milford, Dover) and soil (HC, CP) materials by TSB -grow $n$ B rY cells. Panel A: Oyster

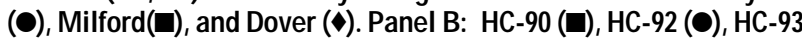

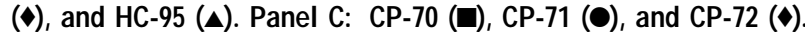
Results are means of single determinations on duplicate cultures containing 1-2.5 $\mathrm{g}$ of material; error bars bracket the range of the duplicate samples; error bars not visible are smaller than the size of the symbol. The dashed lines in each panel indicate the range of ammonium oxalate-extractable and/or hydroxylamine hydrochloride-extractable $\mathrm{Fe}(\mathrm{III})$ in the materials.

to (as a percent of total $\mathrm{Fe}$ ) the $\mathrm{Fe}(\mathrm{II})$ content of the original reduced MSA goethite suspension.

Reduction of Soil and Subsurface Materials. Significant quantities of $\mathrm{Fe}(\mathrm{II})\left(5-15 \mathrm{mmol}^{-1}\right)$ accumulated in media containing soils and subsurface materials that had been inoculated with TSB-grown BrY cells (Figure 7). The total amount of $\mathrm{Fe}(\mathrm{III})$ reduced was 5-50-fold greater than that extractable by either hydroxylamine hydrochloride or ammonium oxalate (Table 2), indicating reduction of crystalline $\mathrm{Fe}$ (III) phases. BrY reduced comparable amounts of Fe(III) in surface soil (e.g., HC-92, E horizon; CP-71, $A_{p}$ horizon), subsoils (e.g., CP-70), and deeper geologic materials (Oyster, Dover, and Milford) characteristic of aquifer sediments. While the percent of $\mathrm{Fe}(\mathrm{III})$ reduced by $\mathrm{BrY}$ in the soil materials ( $\mathrm{HC}$ and CP) correlated with the percent of $\mathrm{Fe}(\mathrm{III})$ extracted by hydroxylamine $\left(\mathrm{r}^{2}=0.93\right.$, excluding HC-92), other correlations for the entire materials set were notevident (properties considered in addition to extractable Fe(III) content included: surface area, \% clay, cation exchange capacity, and organic matter content). The Oyster, HC-90, and CP-70 cultures weretransferred 15 times with continued active $\mathrm{Fe}(\mathrm{III})$ reduction.

Growth of Strain BrY with Goethite Reduction. Lactate-MSA goethitecultures originally inoculated with TSBgrown BrY cells were transferred fivetimes with continued active Fe(III) reduction. The fraction of MSA goethite 


\section{TABLE 2}

Characteristics of Subsurface (Oyster, Milford, Dover) and Soil (HC, CP) Materials

\begin{tabular}{|c|c|c|c|c|c|}
\hline \multirow[b]{2}{*}{ material } & \multirow[b]{2}{*}{$\begin{array}{c}\text { DCB Fe(III) })^{a} \\
\left(\mu \mathrm{mol} \mathrm{Fe} \mathrm{g}^{-1}\right)\end{array}$} & \multicolumn{2}{|c|}{$\% \mathrm{Fe}(\mathrm{III})^{b}$ extracted by } & \multirow{2}{*}{$\begin{array}{l}\% \mathrm{Fe}(\mathrm{III}) \\
\text { reduced } \\
\text { by } \mathrm{BrY} \mathrm{C}^{\mathrm{c}}\end{array}$} & \multirow{2}{*}{$\begin{array}{l}\text { dominant } \\
\text { Fe(III) oxide } \\
\text { phase }\end{array}$} \\
\hline & & $\begin{array}{l}\text { hydroxyl- } \\
\text { amine }\end{array}$ & oxalate & & \\
\hline & 545 & 0.84 & & 18.3 & \\
\hline & & & & & \\
\hline & 145 & & & & \\
\hline & 6 & 0. & 0 & & \\
\hline & 1 & 2. & 1. & 20 & go \\
\hline & & & & 12 & \\
\hline & 6. & & & & \\
\hline & 32 & 0 & 0. & 20 & he \\
\hline & 8. & 0.42 & 0. & 18.9 & hematite \\
\hline P-72 & 752 & 0.45 & 0.2 & 17.6 & hematit \\
\hline
\end{tabular}

${ }^{a}$ Dithionite-citrate buffer-extractable Fe(III). ${ }^{b}$ (Extracted Fe(III) $\div$ DCB $\mathrm{Fe}(\mathrm{III})) \times 100{ }^{c}$ (Total $\mathrm{Fe}(\mathrm{II})$ produced after 21 -day incubation $\div \mathrm{DCB}$ $\mathrm{Fe}(\mathrm{III})) \times 100$.

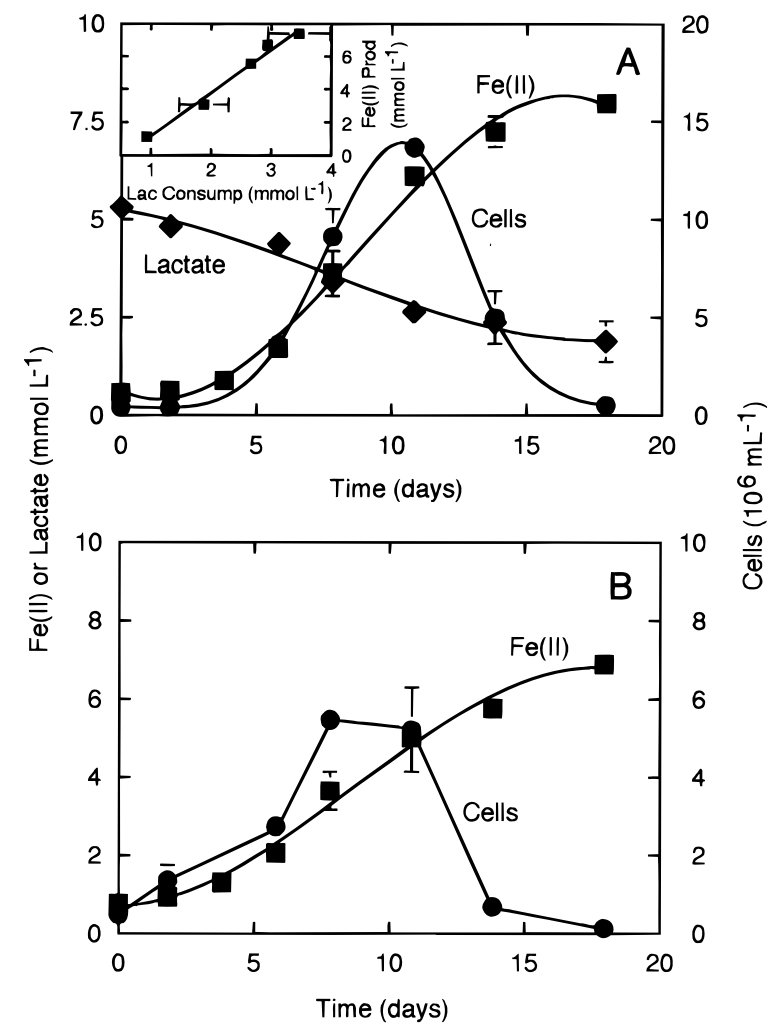

FIGURE 8. Growth of strain BrY in lactate-MSA goethite (A) or $\mathrm{H}_{2}-$ MSA goethite (B) medium inoculated with cells that had been grow $n$ in lactate-MSA goethite medium. The concentration of $\mathrm{Fe}$ (III) in the medium was $500 \mathrm{mmol} \mathrm{L}^{-1}$. Results are means of single determinations on duplicate cultures; error bars bracket the range of the duplicate samples. Inset in panel A shows the relationship betw een $\mathrm{Fe}$ (II) production and lactate consumption during the grow th of BrY in lactate-MSA goethite medium.

reduced did not decrease with successive transfers (mean $\pm \mathrm{SD}=2.5 \pm 0.2 \% ; n=6$ ), demonstrating that the TSB present in the original culture did not enhance the longterm extent of goethite reduction by BrY. In both lactateand $\mathrm{H}_{2}-$ MSA goethite cultures, the production of $\mathrm{Fe}(\mathrm{II})$ was accompanied by an increase in cell numbers (Figure 8). Lactate consumption was concurrent with cell growth and $\mathrm{Fe}(\mathrm{II})$ production (Figure $8 \mathrm{~A}$ ). The ratio of $\mathrm{Fe}(\mathrm{II})$ produced to lactate consumed (2.8; Figure $8 \mathrm{~A}$, inset) was somewhat lower $(30 \%)$ than that expected (4.0) for the oxidation of lactate to acetate and $\mathrm{CO}_{2}$ coupled to $\mathrm{Fe}(\mathrm{III})$ reduction, suggesting significant incorporation of carbon into cell biomass. Theamount of Fe(II) produced $(\approx 8 \mathrm{mmol}$ $\mathrm{L}^{-1}$ ) in these cultures containing $\leq 5 \mathrm{mM}$ lactate was lower than the $12-15 \mathrm{mmol}$ of $\mathrm{Fe}(\mathrm{II}) \mathrm{L}^{-1}$ produced in cultures containing $30 \mathrm{mM}$ lactate (Figure 4), presumably due the carbon requirements for cell growth.

\section{Discussion}

Control Experiments. Theaddition of $0.15 \%$ (wt/ vol) TSB to sterile medium solubilized only a minor amount of amorphous Fe(III) and MSA goethite compared to that solubilized by an equivalent amount of EDTA, which suggests indirectly that the quantity of Fe(III) chelating/ reducing agents introduced to iron(III) oxide-containing media during inoculation with TSB-grown cells was minimal. Considering this low degree of Fe(III) solubilization, it is likely that the modest enhancement of Fe(III) reduction rates (27-41\%) observed with TSB addition was due to a nutritional rather than a Fe(III)-chelating effect such as that observed with compounds like EDTA and NTA in our own (Roden and Zachara, unpublished data) and many other studies of microbial iron(III) oxidereduction (3). These results, together with the finding that the long-term extent of MSA goethitereduction did not decrease with successive transfers of BrY out of TSB-containing medium, indicate that the presence of TSB did not promote Fe(III) reduction through a ligand binding/Fe(III) dissolution process. In addition, the fact that the initial rate and long-term extent of MSA goethite reduction were the same in PIPES- and bicarbonate-buffered medium indicates that the PIPES buffer also did not stimulate Fe(III) reduction through a chelating effect. Thus, patterns of microbial iron(III) oxide reduction observed in thisstudy can beattributed primarily to interactions of the bacteria with the surfaces of the different iron(III) oxide phases.

Surface Area Control of Fe(III) Reduction Rate. Our experiments demonstrated that the initial rate of reduction of individual iron(III) oxides was dependent on the amount of oxide surface area present in the medium (Figure 1). Similar findings were reported by Arnold et al. (38) for hematite reduction by $\mathrm{S}$. putrefaciens (Pseudomonas sp. 200). Collectively, these findings are not unexpected if one assumes that something approaching an excess of cells, relative to available oxide surface area, was present in the medium (true for the lower Fe(III) levels based on results shown in Figure 3; see above), and if direct association of bacteria with surfacesites on theoxideis required to initiate solid-phase Fe(III) reduction (7, 38-40). Rates of Fe(III) reduction began to level off at the highest Fe(III) levels (Figure 1), and in most cases the data approximated a Michaelis-type relationship analogous to that proposed previously $(38,41)$, although complete saturation of Fe(III) reduction rate with respect to $\mathrm{Fe}(\mathrm{III})$ concentration was not observed.

In examining the kinetics of hematite reduction by $\mathrm{S}$. putrefaciens, Arnold et al. (38) added a chelator (NTA) to the medium at varying levels, and hence the relationship between $\mathrm{Fe}(\mathrm{III})$ reduction rate and total $\mathrm{Fe}(\mathrm{III})$ available for reduction (i.e., the sum of solid-phase oxide surface area and soluble Fe(III)) could not be specified. However, other experiments in that study suggested that hematite dissolution by NTA was minimal and that direct bacteria- 
oxide attachment was required for Fe(III) reduction even in the presence of NTA. Thus, the authors argued that hematitereduction kinetics werecontrolled by the reactive mineral surfacearea, a conclusion supported and expanded upon by the results presented here for additional iron(III) oxides.

The initial rate of reduction of different iron(III) oxides present at the same molar concentration was correlated with their specific surface area (Figure 2), a finding which follows logically from the observation that the initial reduction rate of individual iron(III) oxides was correlated with the amount of oxide surface area made available to the bacteria (Figure 1). These results provide explicit experimental evidence for the hypothesized $(3,9)$ relationship between iron(III) oxide surface area and reduction rate across a range of oxide particle types. An exception to the general trend occurred with 2-line ferrihydrite. This solid was highly aggregated and was reduced relatively slowly even though it possessed a higher surface area than any of the goethites (Table 1). Particle aggregation may change the fraction of total surface area that is readily accessible (physically) to the bacteria, a changethat would not necessarily be reflected in simple $\mathrm{N}_{2}$ adsorption measurements of surface area but that could have a major influence on rates of bacterial attachment and Fe(III) reduction.

A recent study (4) of manganese(IV) oxide reduction by S. putrefaciens strain MR-1 (31) showed that highly crystalline, low surface area pyrolusite was reduced more slowly than amorphous, relatively high surface area $\delta-\mathrm{MnO}_{2}$. However, the relationship between manganese(IV) oxide reduction rate and surface area was not linear, as the pyrolusite was reduced only four times more slowly than $\delta-\mathrm{MnO}_{2}$, even though its surface area was more than 250 times lower. In addition, Arnold et al. (38) found that the difference in reduction rate between two forms of hematite was 2-3-fold less than that predicted based on their specific surface areas. These findings, along with our results with 2-line ferrihydrite, indicate that factors such as crystal structure, morphology, and free energy as well as particle aggregation may in some instances have an important influence on rates of microbial metal oxide reduction. Together these considerations lend credence to the cautionary statements of Arnold et al. (38) regarding the use of specific surface area as a quantitativeindicator of amount of iron(III) oxide surface available for microbial adhesion and subsequent $\mathrm{Fe}(\mathrm{III})$ reduction.

In spite of theabovecaveats, our results(Figure2) suggest that specific area provides at least a gross indicator of the relative abundance of iron(III) oxide surface available for microbial attachment and reduction. This apparent dependenceon surface area provides a functional explanation for the major differences in the reduction rate of various types of iron(III) oxides observed in this and many previous studies (3), and in particular for differences in the rates of amorphous versuscrystalline (e.g., goethite, hematite) iron(III) oxide reduction. Because both the concentration of surfacesites present for enzymatic contact and thesolubility of the iron(III) oxides correlatepositively with surface area, we cannot quantitatively differentiate their relative role in controlling initial iron(III) oxide reduction rates. However, our results indicate qualitatively that surface site concentration is the most significant factor.

For the purpose of argument, let us assume that the free energy of formation of an iron(III) oxide $\left(\Delta G^{\circ}\right)$ influences

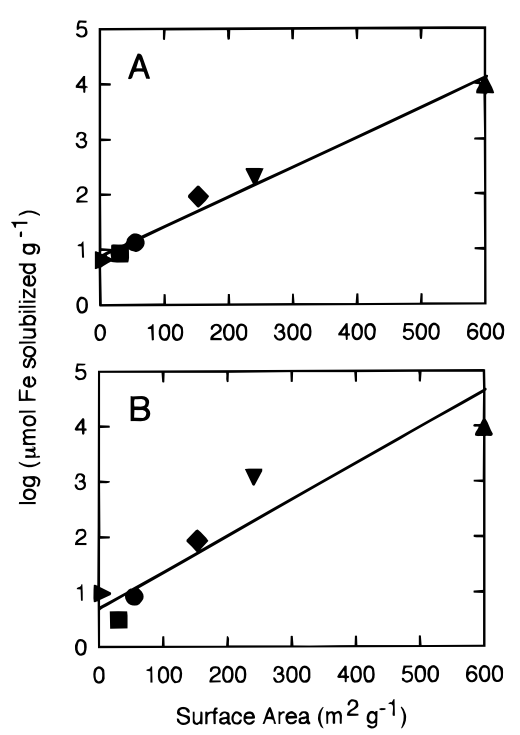

FIGURE 9. Oxalate-extractable (A) and hydroxylamine hydrochlorideextractable (B) Fe content of hematite (solid triangle pointing right), LSA goethite $(\square)$, MSA goethite (O), HSA goethite $(\diamond)$, 2-line ferrihydrite $(\boldsymbol{\nabla})$, and amorphous iron(III) oxide $(\mathbf{\Delta})$ plotted against oxide surface area. The lines correspond to least-squares linear regression fits to the data.

its microbial reducibility by controlling its solubility and other properties of the oxide surface such as the energetics of electron transfer, the strength of $\mathrm{Fe}^{2+}$ adsorption, and the rate of $\mathrm{Fe}^{2+}$ detachment. The observation of a curvilinear relationship between surface area and protonpromoted iron(III) oxide dissolution rate (21), despite a linear correlation between site concentration and surface area, suggests that solid-phase energetic considerations are important for nonreductive dissolution. The curvilinear dissolution rate behavior is an effect of smaller size crystallites (21), which exhibit higher solubility as a result of greater structural disorder and surface tension effects (42). Our extraction results with oxalateand hydroxylamine hydrochloride also demonstrated an exponential relationship between the amount of Fe(III) solubilized and iron(III) oxide surface area (Figure 9). In contrast, we observed a generally linear relationship between initial microbial $\mathrm{Fe}$ (III) reduction rate and surface area (Figure 2). Thermodynamic calculations (including particlesizecorrections for the $\Delta \mathrm{G}^{\circ}$ of the smaller sized oxides according to ref 42) indicate that the free energy change for lactate oxidation coupled to microbial reduction of LSA goethite, MSA goethite, or hematite is 2-4 times lower than for reduction of amorphous iron(III) oxide or HSA goethite (data not shown). However, these oxides exhibited comparable surface area-normalized initial rates of reduction (Table 1). Together these results suggest that the $\Delta G^{\circ}$ of the above oxides was of secondary importance in controlling initial rates of microbial reduction.

We speculated that if oxide surface site concentration limited the initial rate of $\mathrm{Fe}(\mathrm{III})$ reduction, it should be possibleto saturate the surface of iron(III) oxides with cells such that further increases in cell numbers would not lead to a proportional increase in Fe(III) reduction rate. The relationship between $\mathrm{Fe}(\mathrm{III})$ reduction rate and BrY cell density (Figure 3) suggested that a progressive saturation of reduction sites on the iron(III) oxides did occur. These results are analogous to those obtained for the abiotic reductive dissolution of iron(III) oxides by ascorbate, the rate of which becomes saturated at high concentrations of 
reductant and is limited by the amount of ascorbate adsorbed to the oxide surface $(43,44)$. They are also analogous to studies of chelator (e.g., EDTA) adsorption to and dissolution of iron(III) oxides, in which a hyperbolic relationship between themagnitude of chelator adsorption and/or Fe(III) dissolution rate and the initial chelator concentration in solution has been observed (45-47). It should not be inferred from these observations, however, that the cells saturated the iron(III) oxide surface in the sense that organic ligands such as ascorbate or EDTA do, because TEM examination of MSA goethite cultures (48) has revealed that the cells are significantly larger than the oxide particles, which themselves tend to coat the surface of thecells. Nonetheless, if theattachment of iron(III) oxide surfaces to bacterial cell surfacesisassumed to bethecritical step in initiating the reduction process and if this attachment is viewed as a process akin to ligand adsorption, the parallel between our results and the ligand adsorptionoxide reduction/dissolution studies is not unexpected and is consistent with a conceptual model of microbial iron(III) oxide reduction as a surface-controlled process analogous to well-established models of abiotic metal oxidedissolution $(43,49,50)$.

Control of the Long-Term Extent of Iron(III) Oxide Reduction. Our experiment with microbially reduced MSA goethite (Figure 6) that had been washed with $\mathrm{pH} 5$ sodium acetatesuggested that Fe(II) sorption limited the long-term extent of microbial Fe(III) reduction. Thus, the correlation between the extent of Fe(III) reduction and iron(III) oxide surface area (Figure 5) may tentatively be interpreted as a surface concentration/saturation phenomenon such that the amount of a given oxide that can be reduced depends on its surface site concentration as a repository for solubilized Fe(II). We hypothesize that the reduction process is deactivated as surface sites become saturated with sorbed $\mathrm{Fe}(\mathrm{II})$. This phenomenon provides a mechanistic explanation for previously observed differences in the long-term susceptibility of iron(III) oxides of differing degrees of crystallinity (and presumably, different surface areas) to microbial reduction (5-7). It may also account for the persistence of nonmicrobially-reducible Fe(III) in freshwater aquatic sediments (5), which wasshown recently to be in the form of crystalline iron(III) oxides (51).

While our results did not allow identification of the "sorption complex" responsible for site saturation, they are more consistent with an adsorption rather than a solidphase formation reaction. Although the ultimate end product of amorphous $\mathrm{Fe}$ (III) reduction by dissimilatory Fe(III)-reducing bacteria in culture is ultrafine-grained magnetite $(7,34,52)$, magnetite formation lags behind the initial period of $\mathrm{Fe}(\mathrm{III})$ reduction (D. Lovley, personal communication), suggesting that magnetite formation is preceded by ferrous iron saturation of the oxide surface. This process may pose the major limitation on amorphous Fe(III) reduction prior to conversion of the remaining Fe(III) into the mixed iron(II)-iron(III) magnetite. This speculation is supported by the fact that no magnetic material (asjudged by a lack of attraction to a strong handheld magnet) was present in the 30-day-old amorphous Fe(III) cultures depicted in Figure 4. In addition, there was no magnetic material observed in any of the crystalline iron(III) oxide cultures, indicating that formation of magnetite coatings on these oxides was not responsible for cessation of microbial Fe(III) reduction. It should benoted, however, that Coughlin and Stone (53) observed strong
Fe(II) adsorption to goethite and, citing work by others, suggested that Fe(II) adsorption may in fact ultimately lead to the formation of a superficial layer of spinel-type structures $\left(\mathrm{Fe}_{3} \mathrm{O}_{4}\right)$ on crystalline iron(III) oxides. The formation of such structures would likely block further Fe(III) reduction, at least at circumneutral pH (54). It is also possible that precipitation of other solid-phase $\mathrm{Fe}(\mathrm{II})$ compounds e.g., $\left.\mathrm{Fe}(\mathrm{OH})_{2}, \mathrm{FeCO}_{3}, \mathrm{Fe}_{3}\left(\mathrm{PO}_{4}\right)_{2}\right)$ on iron(III) oxide surfaces, some of which may be solubilized by $\mathrm{pH} 5$ sodium acetate, could have been involved in the cessation of microbial Fe(III) reduction in our experiments.

The renewed capacity for MSA goethite reduction upon washing with $\mathrm{pH} 5$ sodium acetate suggests that the reduction process can be reactivated if sorbed Fe(II) and/ or surface $\mathrm{Fe}(\mathrm{II})$-mineral precipitates are removed. This assertion is significant in that the extent and episodicity of iron(III) oxide reduction in soils and sediments may be influenced by reactions with associated phases and ligands that compete for and complex the evolved Fe(II). For example, preliminary experiments indicate that the association of Fe(II) with chelators such as EDTA and NTA is responsible for enhancing the long-term extent of amorphousFe(III) and MSA goethitereduction (Roden and Zachara, unpublished data).

Cell Growth Coupled to Crystalline Iron(III) Oxide Reduction. Strain BrY was previously shown to obtain energy for cell growth by coupling the oxidation of lactate $\mathrm{or}_{2}$ to thereduction of amorphousFe(III) (30). Theresults presented here (Figure 8) demonstrate that BrY can also grow by coupling the oxidation of lactate and $\mathrm{H}_{2}$ to the reduction of synthetic goethite. Although several Bacillus, Clostridia, and Pseudomonas strains (55-59), a Coryne bacterium strain (60), and sediment enrichment cultures (18, 39, 61-63) have been shown to reduce significant quantities of goethite and/or hematite during growth in complex glucose-based medium, in all of these cultures $\mathrm{Fe}(\mathrm{III})$ reduction was a minor path way for electron disposal during metabolism of fermentable substrates (3). Two organisms, Geobacter metallireducens $(7,64)$ and S. putrefaciens $(65,66)$, capable of obtaining energy for growth from the reduction of amorphous Fe(III) have been shown to reduce small amounts of goethite and hematite in anaerobic growth medium $(7,38)$. However, neither of these organisms was tested for the ability to grow and transfer on a medium containing these iron(III) oxides. A recent study demonstrated the growth of $\mathrm{S}$. putrefaciens with magnetite $\left(\mathrm{Fe}_{3} \mathrm{O}_{4}\right)$ as an electron acceptor at $\mathrm{pH} 6$ (54), a condition which may readily occur in someanaerobic soils and sediments. Our demonstration of growth of BrY with goethite thus expands the list of crystalline iron(III) oxides that can serve as electron acceptors for the growth of Fe(III)-reducing bacteria. The potential for growth with goethite or hematite is likely to have broad environmental significance as these are the most common forms of crystalline iron(III) oxides present in soil and sedimentary environments (8).

The quantity of $\mathrm{Fe}(\mathrm{II})\left(\approx 10 \mathrm{mmol} \mathrm{L}^{-1}\right)$ produced during growth of BrY in media with $500 \mathrm{mmol} \mathrm{L}^{-1}$ goethite was several times lower than that produced by $\operatorname{BrY}$ (30), G. metallireducens (7), or Desulfuromonas acetoxidans (34) during growth in media with comparable concentrations (100-200 mmol L $\mathrm{mm}^{-1}$ ) of amorphous Fe(III). Accordingly, the number of cells produced during growth on goethite was an order of magnitude lower. However, when normalized to the amount of $\mathrm{Fe}(\mathrm{III})$ reduced during the active 
growth phase of the cultures, thequantity of cells produced with MSA goethite as theelectron acceptor $\left(2.5 \times 10^{6} / \mu \mathrm{mol}\right.$ of $\mathrm{Fe}$ ) was comparable to that observed during growth of $\mathrm{BrY}$ and other dissimilatory Fe(III)-reducing bacteria with amorphous Fe(III) $(3.8-6.4 \times 10 \% / \mu \mathrm{mol}$ of Fe; 7, 30, 34). These findings suggest that a consistent amount of energy for growth is generated during iron(III) oxide reduction regardless of the form of oxide being utilized, and together with our other results imply that the potential for Fe(III)reducing bacteria to grow and reproduce in situ will be limited by the site concentration of whatever iron(III) oxides are present in the soil or sediment matrix. As noted previously, differentiron(III) oxides have very different free energies of formation and solubility, and the conclusion of a common energy yield for microbial $\mathrm{Fe}(\mathrm{III})$ reduction independent of iron(III) oxide structure contradicts this thermodynamic reality. More refined studies, including careful consideration of the end products of Fe(III) reduction, are required to elaborate the energetics of microbial reduction of different iron(III) oxides.

Implications for Natural Systems. Consistent with the ability of BrY to reduce significant quantities of synthetic crystalline iron(III) oxides, studies with natural soil and surface materials indicated that strain BrY reduced iron(III) oxides operationally defined as crystalline by the different extractions (Table 2). Given our observation that $\mathrm{Fe}$ (II) sorption might limit iron(III) oxide reduction by surface saturation (Figure6), we speculated that BrY should have reduced a greater fraction of the iron(III) oxide pool in natural materials with accessory phases capable of sorbing $\mathrm{Fe}(\mathrm{II})$ in competition with iron(III) oxide surfaces (e.g., in soils $\mathrm{CP}$ and $\mathrm{HC}$ ). Moreover, we speculated that iron(III) oxide reduction would be greatest in the $\mathrm{HC}$ materials as these contained 2:1 layered silicates with high divalent cation adsorption capacity. Thesehypotheses were not affirmed by the experimental data (Table 2), and in general, good correlations between the extent of Fe(III) reduction and solid-phase properties werenot evident with our existing data base. With respect to the Fe(II) sorption process, it may be that iron(III) oxides are the strongest sorbents because of the high stability of the Fe(III)-OFe(II) interaction (67). Thus, iron(III) oxide surfaces may become saturated with Fe(II) before appreciable sorption to other phases occurs. It is clear that more challenging measurements of other properties such as (1) the surface area, solubility, and degree of crystallinity of the iron(III) oxide fraction; and (2) the identity and concentrationvariant sorption capacity of other $\mathrm{Fe}(\mathrm{II})$ sorbent phases will be required to interpret controls on microbial Fe(III) reduction in natural materials.

It was notable, however, that theamount of microbiallyreducible Fe $(\mathrm{III})$ in the natural materials $(\approx 10-20 \%$ of DCB $\mathrm{Fe}(\mathrm{III}))$ was comparable to the amount of HSA goethite reduced by $\mathrm{BrY}$. The $\mathrm{CP}$ and $\mathrm{HC}$ soils are known to contain Al-substituted goethites and hematites (28). Aluminum substitution yields goethites of small particle size and high surfacearea $(68,69)$ and yields crystallites of greater disorder and higher solubility $(42,70)$, factors both of which may influence their microbial reducibility. The HSA goethite and Al-substituted goethites of comparable surface area are probably good models for natural, crystalline iron(III) oxides that are characterized by high surface area and compositional impurities $(69,71-75)$. These properties of natural crystalline iron(III) oxides may allow them to function as more effective electron acceptors for dissimila- tory Fe(III)-reducing bacteria than has been previously recognized.

Although it was not possible to determine cell numbers in our soil iron(III) oxide cultures due to interference from the sand or clay matrix, the finding that the cultures could be transferred repeatedly with continued active Fe(III) reduction indicates that BrY was able to obtain energy for growth from the reduction of these natural crystallineiron(III) oxides. Together with our results with synthetic goethite, these findings suggest that Fe(III)-reducing bacteria may be able to grow and remain active over extended periods of time in anaerobic soil and sedimentary environments where crystalline iron(III) oxides are the dominant forms of Fe(III). This assertion is supported by the recent observation that a major portion of the crystalline iron(III) oxide content of aquifer sediments was reduced within the oldest ( $\approx 15$ years) region of a landfill leachate contaminant plume in Denmark (76). It is possible that continual removal of surface-associated Fe(II) (e.g., complexation by organic compounds present in thelandfill leachate passing through the aquifer sediments) was responsible for enhancingthelong-term extent of crystallineFe(III) reduction in thissubsurface environment. These processes may have important implications regarding the release of solubleFe ${ }^{2+}$ (a common inorganic groundwater contaminant) as well as the capacity for organic contaminant oxidation coupled to microbial iron(III) oxide reduction in subsurface environments $(10,13)$, and the potential for generation and/ or loss of reactive Fe(II) surfaces capable of catalyzing organic contaminant-degrading redox reactions such as reduction of nitro-substituted aromatic compounds (77) and reductive dehalogenation of chlorinated organic contaminants ( $Y$. Gorby, manuscript in preparation). More detailed studies of factors controlling the rate, long-term extent, and endproducts of microbial reduction of various iron(III) oxides present in chemically complex soil and sedimentary environments are required to support both field determinations of dissolved and solid-phase geochemical distributions as well as assessments of the direct or indirect contaminant degradation potential offered by microbial iron(III) oxide reduction.

\section{Acknowledgments}

We thank Clint Church for technical assistance; Jim Fredrickson and Yuri Gorby for adviceand discussion during the course of this research; and Frank Caccavo, Jim Fredrickson, and Derek Lovley for helpful comments on the manuscript. We also thank Matilde Urrutia for providing TEM micrographs of the iron oxides, discussion of experimental results, and review of the manuscript. The BET surface area measurements were made by Quantachrome Corp., Syosset, NY. This work was funded in part by the U.S. Department of Energy Office of Health and Environmental Research, Subsurface ScienceProgram, and is a contribution from the Co-Contaminant Chemistry and Deep Microbiology subprograms. Pacific Northwest Laboratory is operated for the U.S. Department of Energy by BattelleM emorial Institute under Contract DE-AC06-76RLO 1830.

\section{Literature Cited}

(1) Ponnamperuma, F. N. Adv. Agron. 1972, 24, 29-96

(2) Breemen, N. v. In Iron in soils and clay minerals; Stucki, J. W., Goodman, B. A., Schwertmann, U., Eds.; D. Reidel Publishing Co.: Dordrecht, 1988; pp 797-809.

(3) Lovley, D. R. Microbiol. Rev. 1991, 55, 259-287. 
(4) Lovley, D. R.; Phillips, E. J. P. Environ. Sci. Technol. 1991, 25, $1062-1067$.

(5) Lovley, D. R.; Phillips, E. J. P. Appl. Environ. Microbiol. 1986, 52, $751-757$.

(6) Lovley, D. R.; Phillips, E. J. P. Appl. Environ. Microbiol. 1987, 53, $1536-1540$.

(7) Lovley, D. R.; Phillips, E. J. P. Appl. Environ. Microbiol. 1988, 54, $1472-1480$.

(8) Schwertmann, U.; Taylor, R. M. In Mineralsin soil environments; Dixon, J. B., Weed, S. B., Eds.; Soil Science Society of America: Madison, WI, 1977; pp 145-180.

(9) Lovley, D. R. Geomicrobiol. J. 1987, 5, 375-399.

(10) Lovley, D. R.; Baedecker, M. J.; Lonergan, D. J.; Cozzarelli, I. M.; Phillips, E. J. P.; Siegel, D. I. Nature 1989, 339, 297-299.

(11) Heijman, C. G.; Holliger, C.; Glaus, M. A.; Schwarzenbach, R. P.; Zeyer, J. Appl. Environ. Microbiol. 1993, 59, 4350-4353.

(12) Albrechtsen, H. J. In Hydrocarbon bioremediation; Hinchee, R. E., Alleman, B. C., Hoeppel, R. E., Miller, R. N., Eds.; Lewis Publishers: Boca Raton, FL, 1994; pp 418-423.

(13) Lovley, D. R.; Woodward, J. C.; Chapelle, F. H. Nature 1994, 370, $128-131$.

(14) Lipczynskakochany, E.; Harms, S.; Milburn, R.; Sprah, G.; Nadarajah, N. Chemosphere 1994, 29, 1477-1489.

(15) Lyngkilde, J.; Christensen, T. H. J. Contam. Hydrol. 1994, 10, 291-307.

(16) Cozzarelli, I. M.; Herman, J. S.; Baedecker, M. J. Environ. Sci. Technol. 1995, 29, 458-469.

(17) Rossello-Mora, R. A.; Caccavo, F.; Osterlehner, K.; Springer, N.; Spring, S.; Schuler, D.; Ludwig, W.; Amann, R.; Vanncanneyt, M.; Schleifer, K. H. Syst. Appl. Microbiol. 1994, 17, 569-573.

(18) Lovley, D. R.; Phillips, E. J. P. Appl. Environ. Microbiol. 1986, 51, 683-689.

(19) Schwertmann, U.; Cornell, R. M. Iron oxides in the laboratory; Weinheim: New York, 1991.

(20) Goodman, B. A.; Lewis, D. G. J. Soil Sci. 1981, 32, 351-363.

(21) Schwertmann, U.; Cambrier, P.; Murad, E. Clays Clay Miner. 1985, 33, 369-378.

(22) Davis, J. A.; Leckie, J. O. J. Colloid InterfaceSci. 1978, 67, 90-107.

(23) Dzombak, D. A.; Morel, F. M. M. Surface complexation modeling: hydrous ferric oxide; John Wiley \& Sons: New York, 1990

(24) Zinder, B.; Furrer, G.; Stumm, W. Geochim. Cosmochim. Acta 1986, 50, 1861-1869.

(25) Langmuir, D. Am. J. Sci. 1971, 271, 147-156.

(26) Rai, D.; Zachara, J. M.; Ainsworth, C. C.; Eary, L. E.; Sass, B. M. Physiochemical measurements of soils at solid waste disposal sites; Report EA-4544; Electric Power Research Institute: Palo Alto, CA, 1986

(27) Zachara, J. M.; Ainsworth, C. C.; Cowan, C. E.; Resch, C. T. Soil Sci. Soc. Am. J. 1989, 53, 418-428.

(28) Zachara, J. M.; Smith, S. C.; Kuzel, L. S. Geochim. Cosmochim. Acta, in press.

(29) Gorby, Y. A. Presented at the American Society of Microbiology Annual General Meeting, Atlanta, GA, May 1993.

(30) Caccavo, F.; Blakemore, R. P.; Lovley, D. R. Appl. Environ. Microbiol. 1992, 58, 3211-3216.

(31) Canfield, D. E. Geochim. Cosmochim. Acta 1989, 53, 619-632.

(32) Stevens, T. O.; McKinley, J. P.; Fredrickson, J. K. Microb. Ecol. 1993, 25, 35-50.

(33) Suter, D.; Siffert, C.; Sulzberger, B.; Stumm, W. Naturwissenschaften 1988, 75, 571-573.

(34) Roden, E. E.; Lovley, D. R. Appl. Environ. Microbiol. 1993, 59 $734-742$.

(35) Tessier, A.; Campbell, P. G. C.; Bisson, M. Anal. Chem. 1979, 51, 844-851.

(36) Rapin, F.; Tessier, A.; Campbell, P. G. C.; Carignan, R. Environ. Sci. Technol. 1986, 20, 836-840.

(37) Hayes, K. F. Ph.D. Thesis, Stanford, 1987.

(38) Arnold, R. G.; DiChristina, T. J.; Hoffmann, M. R. Biotechnol. Bioeng. 1988, 32, 1081-1096.

(39) Munch, J. C.; Ottow, J. C. G. Ecol. Bull. 1983, 35, 383-394.

(40) Tugel, J. B.; Hines, M. E.; Jones, G. E. Appl. Environ. Microbiol. 1986, 52, 1167-1172.
(41) Arnold, R. G.; Olson, T. M.; Hoffmann, M. R. Biotechnol. Bioeng. 1986, 28, 1657-1671.

(42) Trolard, F.; Tardy, Y. Geochim. Cosmochim. Acta 1987, 51, 945 947.

(43) Hering, J. G.; Stumm, W. In Mineral-water interfacegeochemistry; Hochella, M. F., White, A. F., Eds.; Mineralogical Society of America: Washington, DC, 1990; Vol. 23, pp 427-464.

(44) Suter, D.; Banwart, S.; Stumm, W. Langmuir 1991, 7, 809-813.

(45) Rubio, J.; Matijevic, E. J. Colloid InterfaceSci. 1979, 68, 408-421.

(46) Rueda, E. H.; Grassi, R. L.; Blesa, M. A. J. Colloid Interface Sci. 1985, 106, 243-246.

(47) Chang, H. C.; Healy, T. W.; Matijevic, E. J. Colloid Interface Sci. 1983, 92, 469-478.

(48) Urrutia, M. M.; Fredrickson, J. K.; Zachara, J. M. Presented at the Soil Science Society of America Annual Meeting, Seattle, WA 1994.

(49) Stumm, W. Chemistry of the solid-water interface; John Wiley \& Sons: New York, 1992.

(50) Stone, A. T.; Morgan, J. J. In Aquatic surface chemistry; Stumm, W., Ed.; John Wiley \& Sons: New York, 1987; pp 221-254.

(51) Phillips, E. J. P.; Lovley, D. R.; Roden, E. E. Appl. Environ. Microbiol. 1993, 59, 2727-2729.

(52) Lovley, D. R.; Stolz, J. F.; Nord, G. L.; Phillips, E. J. P. Nature 1987, 330, 252-254.

(53) Coughlin, B. R.; Stone, A. T. Environ. Sci. Technol. 1995, 29, $2445-2455$

(54) Kostka, J. E.; Nealson, K. H. Environ. Sci. Technol. 1995, 29, 25352540.

(55) Troshanov, E. P. Microbiology 1969, 38, 528-535.

(56) Ottow, J. C. G. Oecologia 1971, 6, 164-175.

(57) Ottow, J. C. G.; Glathe, H. Soil Biol. Biochem. 1971, 3, 43-55.

(58) deCastro, A. F.; Ehrlich, H. L. Antonie van Leeuwenhoek 1970, $36,317-327$

(59) Munch, J. C.; Ottow, J. C. G. Soil. Sci. 1980, 129, 15-21.

(60) Pfanneberg, T.; Fischer, W. R. Zbl. Mikrobiol. 1984, 189, 167172.

(61) Jones, J. G. J. Appl. Bacteriol. 1983, 54, 305-310.

(62) Jones, J. G.; Gardener, S.; Simon, B. B. J. Gen. Microbiol. 1983, 129, 131-139.

(63) Jones, J. G.; Gardener, S.; Simon, B. M. J. Gen. Microbiol. 1984, $130,45-51$.

(64) Lovley, D. R.; Giovannoni, S. J.; White, D. C.; Champine, J. E.; Phillips, E. J. P.; Gorby, Y. A.; Goodwin, S. Arch. Microbiol. 1993, 159, 336-344.

(65) Meyers, C. R.; Nealson, K. H. Science 1988, 240, 1319-1321.

(66) Lovley, D. R.; Phillips, E. J. P.; Lonergan, D. J. Appl. Environ. Microbiol. 1989, 55, 700-706.

(67) Sherman, D. M. Phys. Chem. Miner. 1987, 14, 355-363.

(68) Lewis, D. G.; Schwertmann, U. Clay Miner. 1979, 14, 115-125.

(69) Norrish, K.; Taylor, R. M. J. Soil Sci. 1961, 12, 294-306.

(70) Tardy, Y.; Nahon, D. Am. J. Sci. 1985, 285-303.

(71) Campbell, A. S.; Schwertmann, U. J. Soil Sci. 1984, 35, 569-582.

(72) Bingham, J. M.; Golden, D. C.; Bowen, L. H.; Buol, S. W.; Weed S. B. Soil Sci. Soc. Am. J. 1978, 42, 816-825.

(73) Bingham, J. M.; Golden, D. C.; Buol, S. W.; Weed, S. B.; Bowen, L. H. Soil Sci. Soc. Am. J. 1978, 42, 825-830.

(74) Kuhnel, R. A.; Roorda, H. J.; Steensma, J. J. Clays Clay Miner. 1975, 23, 349-354.

(75) Schwertmann, U. Adv. Soil Sci. 1984, 1, 171-200.

(76) Heron, G.; Christensen, T. H. Environ. Sci. Technol. 1995, 29, 187-192.

(77) Heijman, C. G.; Grieder, E.; Holliger, C.; Schwarzenbach, R. P. Environ. Sci. Technol. 1995, 29, 775-783.

Received for review August 21, 1995. Revised manuscript received December 18, 1995. Accepted December 20, $1995 .{ }^{\otimes}$

\section{ES9506216}

${ }^{\otimes}$ Abstract published in Advance ACS Abstracts, March 1, 1996. 